\title{
Professional Ethics and Disciplinary System in the KCA
}

\author{
Albulena U. Ukimeraj, PhD. Cand. \\ Faculty of Law - Criminal Law Department \\ University of Tirana, Albania
}

\begin{abstract}
The term "ethics" comes from the Greek word 'ethos/ethikos', which means 'tradition, custom or habit". On the other hand, the science that addresses the requirements/duty to act ethically is called Deontology. In exercising the legal profession, Deontology is found as a discipline incorporating a set of principles and rules which must be acknowledged and adhered to by an exercising lawyer in his/her profession. The conduct of lawyers must be exemplary both in exercising profession and outside, in accordance with the dignity inherent to the profession. In recognizing principles and rules of the Code of Professional Conduct and deontology, lawyers must also adhere in their own professional conduct. In exercising their functions, all lawyers are under oath and must live to the commitment of strict adherence and full willingness to an Ethical Code of the profession. The Code of ethics determines the rules of behaviour, which must be adhered to by all lawyers in exercising their profession and rendering their services, to maintain and uphold the dignity and reputation of the Bar Profession. Failure to know the code of ethics does not justify any breach that a lawyer may commit. The idea of addressing this topic stems from the fact that often, lawyers as legal professionals come to confront with their Code of Professional Ethics. Therefore, considering the role and relevance of ethics in the bar profession, in this paper, I have elaborated on the legal grounds of KCA foundation, the regional coverage of the KCA, with a special emphasis on the professional legal ethics and the disciplinary system established by the Chamber of Advocates of Kosovo, a constitutionally established institution, disciplinary proceedings and measures imposed on the lawyers in case of breaches of their own Professional Ethics, concluding with basic principles of conduct and service provision by lawyers.
\end{abstract}

Keywords: Ethics, Lawyers, Disciplinary System, Chamber of Advocates

\section{Introduction}

It shall never suffice talking about ethics. Ethical rules must be embedded into the conviction and awareness of each of us, and even more in the legal professionals, such as the lawyers.

The Constitution of the Republic of Kosovo, in its seventh chapter, provides on the Bar Profession as a constitutional Category. Article 111 of the Constitution explicitly provides that "Advocacy in an independent profession"1, a trade in providing legal counselling to natural and legal persons in defence of their rights, freedoms and interests, in compliance with the legal order.

The Kosovo Chamber of Advocates is an independent organization of a public nature, and builds upon the three basic principles; Self-organization, Self-Funding and Self-Regulation. 
The KCA is also the sole authority in the Republic of Kosovo mandated to license lawyers.

The Kosovo Chamber of Advocates was established as an independent organization with the adoption of the Law on the Bar and Legal aid by the Kosovo Assembly on 19 December 1973, effective on 10 June 1974.

\section{Organization and operations of the Kosovo Chamber of Advocates as a constitutional institution}

The institution of the Kosovo Chamber of Advocates incorporates the following bodies: General Conference - held once a year to address matters of interest for the Bar. The General Conference is comprised of all active lawyers of the KCA;

The KCA Assembly - shall have the following powers: Election of the President and his deputy; Election of Disciplinary Committees; Election of the Audit Committee; Adoption of the Code of Professional Ethics, the Bar association Statute, Lawyer's remuneration Fee; disciplinary Regulation; Regulation for the work of Assembly and the Regulation on Mandatory Continued Legal Education of lawyers; Adoption of the budget of the Chamber; Adoption of the annual report; Decisions on other issues, envisaged by the Statute of the Bar association; Review of all matters related to the performance of activities of advocacy and advocacy position; Review of the report of the supervisory body; Debate and issuance of positions and decisions regarding the progress of the work of KBA.

KCA President - shall have the following powers: chairs and manages the KBA; represents the KBA; chairs the solemn oath procedure; allows payments from the KBA cashbox up to the limit set by the Board and decides on their expenditure; oversees the work of the Executive Director; performs other tasks in accordance with the Law on the Bar, this Statute and other normative acts, coordinates the daily activities of KBA as stipulated by law.

KCA Board - composed of the KBA President, the previous President of KBA, Vice President, 7 (seven) members Chairmen of Regional Branches and 1 (one) member outside KBA. Powers of the Board include: proposes the normative acts for adoption by the Assembly; sets the registration fee, the membership fee and the fee for other obligations of lawyers, practitioners and volunteer members; makes the proposal for the budget, account and balance of KBA and submits it to the Assembly for approval; requests the initiation of disciplinary proceedings, if this procedure is not initiated by authorized parties.

Supervisory Council - consists of five members elected by the Assembly. Powers of the Supervisory Council include:

Examine financial business of the KCA and compile a report on such examination, and submit the report to the KCA Assembly for approval.

Disciplinary bodies based on the Chamber Statute are: Office of the Disciplinary Counsel, Disciplinary Committee, Complaints Committee.

The Office of the Disciplinary Counsel initiates, receives and reviews any reports against the lawyers and law practitioners.

Disciplinary Committee - consists of five members, who are elected by the Assembly of the KCA.

Complaints Committee, a second instance body ruling on complaints filed against decisions of the Board, and disciplinary complaints.

The grounds for the establishment and operations of the KCA are:

Constitution of the Republic of Kosovo, Article 111

Law on the Bar

Statute of the Chamber of Advocates of Kosovo 
Code of Professional Ethics of the KCA

Regulation on Regional Branches

Regulation on Disciplinary Proceedings

Regulation on Compulsory Continued Legal Education for Advocates

Regulation on Spatial and Technical Conditions of Law Firms

Regulation on Financial Management

Regulation on KCA Staff

\section{Professional ethics of lawyers}

When talking about the role of lawyers in society, we need to take into consideration the fact that the profession was already established in ancient Athens and later in Ancient Rome. In Athens, lawyers were the orators, who could provide legal advice to friends, without being entitled to demand, prior or after service, any monetary remuneration, as it is done today in the free profession of lawyers.

The bar profession is an important pillar for the development of the justice system in any country, and definitely a key supporter in justice administration, both in criminal and civil law. The bar profession is not only related to the professional qualifications in the fields of law where such a lawyer exercises his/her profession, in criminal, civil, commercial and family law, but above all, the bar profession must be grounded upon moral and ethical principles, embedded in the Code of Ethics.

\section{Obligations of a lawyer, pursuant to the Code of Professional Ethics, are:}

To render services and act in a professional, conscious, dignified manner in compliance with the Law on the Bar, Statute and other acts of the KCA. The basic principles of the Code of Ethics for Advocates, principles and rules of conduct are stipulated to preserve honour, dignity and reputation of the bar profession. Such fundamental principles are incorporated in the Solemn Oath taken by lawyers in Kosovo in their licensing. Specifically, they must focus on observing and completing Compulsory Continued Legal Education, the stance of lawyers towards their parties, other lawyers, courts, etc. , diligence in their public appearances and private lives; protection of interests of their clients only by remedies and actions in compliance with the law and dignity of the bar profession; preservation of independence and observation of professional ethics.

A lawyer is bound to preserve professional confidentiality, in compliance with the Statute and Code, thereby strengthening the trust of clients, judicial authorities and other authorities he/she appears before. A lawyer shall not favour any political positions or membership in exercising profession; A lawyer should not accept duties that are not in compliance with legal practice and that would damage his/her independence, reputation and prestige. It is contradictory to the honour and reputation of the bar profession to solicit clients, provision of blank authorizations, promise provisions, cooperation with lay men and invoking close social ties.

In an established society of respect for rule of law, lawyers have a special role. A lawyer must serve interests of justice and rights and freedoms entrusted and demanded for protection, and they shall be bound to defend not only the matter of the client, but also advice them.

\section{KCA Disciplinary System and Proceedings}

Before the disciplinary bodies of the KCA, lawyers appear for minor and severe violations of profession and reputation of bar profession. A severe breach is damage of bar profession reputation, and any breach of official duty and the Code of Ethics, which is severe due to the relevance of good endangered, nature of official duty in breach, severity of material 
damage, or other consequences, while a light violation is breach of official duty, reputation and Code of Ethics at lower degree.

Disciplinary bodies of the KCA are:

1. Office of the Disciplinary Counsel;

2. Disciplinary Committee;

\section{Appeals Committee.}

Another sphere of activity in the exercise of profession is the narrow professional sphere. In exercising his profession, a lawyer must demonstrate professionalism and ensure that his professional actions are in compliance with the procedural law, material law and case law, in order to maintain quality of defence and avoid breach of principles of a regular legal process. In such circumstances, disciplinary breaches would be the actions taken repeatedly by a lawyer in violation of the rules of civil proceedings, actions that would result into unwanted results for the client, such as e. g. missing on a timeline of appeal, for several times, would make cause for disciplinary proceeding. Since a poor quality defence or representation by a lawyer would make grounds for such exercise of profession to be considered violation of a due process, which is in turn protected by criteria set forth by the European Convention and the Constitution of the Republic of Albania.

Any person may demand initiation of disciplinary investigation against a lawyer. Such demand may be made by filing a disciplinary claim report, which is made only in written, in any of the KCA Regional Offices, or directly with the Office of the Disciplinary Counsel at the KCA Headquarters. Such report shall contain: name, address and phone number of the person demanding investigation; name, address and phone number of the lawyer to be reviewed; a description of conduct demanded for review and other supporting documents. Such a claim report is submitted to the Office of the Disciplinary Counsel, who in turn reports to the Disciplinary Committee, consisting of five advocates elected by the KCA Assembly. The Disciplinary Committee appoints a disciplinary panel of three members, which in turn holds a hearing to determine whether such violation was committed. The session shall hear the responding lawyer, the evidence filed and statements of witnesses and experts. Should the panel decide such violations were committed a disciplinary measure shall be imposed. The Appeals Commission is the second tier body for disciplinary complaints.

\section{What are the disciplinary measures that may be imposed by the KCA to a lawyer?}

Disciplinary measures that may be imposed on lawyers are: warning; fine (of up to 5000 Euros); losing the right to practice bar from six (6) months to five (5) years; losing the right to practice bar from five (5) to ten (10) years, permanent loosing of right to practice bar.

For minor violations of bar duties and reputation, warning or fine may be imposed to the lawyer.

For gross violations of duty and reputation of the Bar, all measures above may impose.

All disciplinary proceedings taken against a lawyer are geared towards shedding light on the relations of the lawyer in his exercise of profession, and the position of disciplinary bodies of the Kosovo Chamber of Advocates, which determine the existence of unprofessional conduct of such a lawyer, conduct which may include action in violation of provisions of law, statute and Code of Ethics, and failure to render services at the level required, which are apparently under the expected performance of a lawyer.

\section{Case of the Disciplinary Office of the Kosovo Chamber of Advocates}

Pursuant to the Report no. 80-4/2014, of 30 September 2014, the Office of the Disciplinary Counsel of the KCA, the claimant has requested from the KCA to initiate disciplinary proceedings against a lawyer member of the KCA based on a Report (registered with the KCA as no. 80/2014 of 07/08/14), thereby claiming that the lawyer reported has committed a violation of legal provisions of the KCA Statute, and the Code of Professional Ethics, thereby requesting that disciplinary sanctions 
are imposed against such lawyer. Upon forwarding such report to the lawyer for his reply to the claim report, and had received his reply stating to not have committed any disciplinary breach of the Code of Professional Ethics, the Office of the Disciplinary Counsel issued a Decision initiating investigation against the lawyer, because due an omission, the lawyer had missed the timeline for using an extraordinary remedy, thereby failing to use such remedy.

The Disciplinary Counsel reviewed the claim report no. $80 / 2014$ of $07 / 08 / 14$, to initiate disciplinary proceedings, and pursuant to Article 12 of the Law on the Bar no. 04/L-193, OG-no: 20/31 May 2013, in conjunction with Articles 106. 3 and 13 of the KCA Statute, of date 16/11/2013, pursuant to Articles 22 and 84 of the Bar Association Code of Professional Ethics, and Article 19 of the Regulation on Disciplinary Proceedings of the KCA of date 16/11/2013, to initiate disciplinary proceedings and to be forwarded to the KCA Disciplinary Committee, upon administration of all evidence submitted.

From an analysis of case files, the Office of the Disciplinary Counsel found that the lawyer under review had committed a disciplinary breach, due to the fact that the respondent had acted in contradiction to ethical provisions, and as such, in contradiction to a lawyer's ethics.

From the case files, it was found that the respondent had been authorized by the claimant, and had represented the claimant in judicial proceedings. From a ruling of the Court of Appeals in Prishtina, it was evidenced that the respondent had been authorized to represent the claimant.

The Office of the Disciplinary Counsel requested from the Basic Court in Prishtina to corroborate the claim of the claimant in relation to failure of the lawyer to inform the party on the reception of a ruling of the Court of Appeals. As per request of the Office of the Disciplinary Counsel, the Basic Court in Prishtina, on 22. 08. 2014, provided a reply, thereby attaching a personal delivery slip, from which it was determined that the respondent had received the ruling of the Court of Appeals on 12. 07.2013 , simultaneously being the date from which the timeline started counting for the use of an extraordinary legal remedy. Failure to use the timeline of three months that might have been used to file Revision was considered by the ODC to be a continued breach, which also affected the extension of the statutory limitation, all pursuant to the KCA Statute, Article 106 para3 and Article 13, in conjunction with the Code of Professional Ethics of Lawyers, Articles 22 and 84.

Based on all the above, it was found that the proceedings shall be initiated before the KCA Disciplinary Committee, and consequently summon: the Disciplinary Counsel, the claimant filing the report, and the responding Lawyer, because elements of a breach of Code of Ethics have been found.

Upon review hearing held, the Disciplinary Committee confirmed the report of the Disciplinary Counsel, and imposed the lawyer a disciplinary measure of a fine of 800 Euros. Upon filing complaint to the second instance, the Complaint Committee, the second instance Committee had lowered the fine to 600 Euros.

\section{Conclusion}

Amongst other matters to be taken into account in resolving disputes related to Ethics, one must obey moral and ethical standards and principles embedded into the lawyers' professional and an aspiration for the advocates. Indeed, these standards are relevant for the Bar profession, as an important segment of the justice system in the Republic of Kosovo.

Such principles are numerous, and are related to morals and qualities of character: honesty, integrity, impartiality, moderation, intellectual punctuality, legal accuracy and knowledge, and preparedness and reliability.

The lawyers' performance requirements are built upon principles and ethical conduct, thereby identifying each important ethical consideration in specific situations, and actions taken in compliance with professional ethical standards, and also avoiding any possible conflict of interest, and demonstrating professional conduct in all relations with others, and acknowledging the importance of pro bono contribution to the legal practice and in exercising the profession.

Ethics is paid special attention in the $21^{\text {st }}$ century, and this is best proven by the fact that in most of Law School curricula, ethics is already a specific course, thereby preparing the young generations for such standards in entering the legal profession.

The Chamber of Advocates of Kosovo has for long established Compulsory Continued Legal Education for Advocates, and in this regard, lawyers in Kosovo are bound to attend a mandatory number of hours in CCLE, and that includes courses on professional ethics and disciplinary system at the KCA, with $25 \%$ of hours (credit points) of CCLE in this area. 
The Chamber of Advocates' Disciplinary Counsel is the sole authority with the mandate and full jurisdiction to sanction the advocates, with a purpose of increasing efficiency and effectiveness, thereby contributing into the regulation, the operations of services rendered and counselling offered by Lawyers, thereby aiming for a clear definition of duties, rights and responsibilities of lawyers, in relation to the Chamber, clients, other institutions and their own peers (mutual relations).

By observing the Code of Professional Ethics and proper enforcement of disciplinary procedures, we aim to ensure better access for all professional lawyers in providing legal advice, and for those to be used by the citizens of the Republic of Kosovo, and the justice system generally.

Disciplinary proceedings initiated by claimants are for the lawyers amongst the most important and most sensitive matters in the organization and operations of disciplinary authorities in the KCA, but also the professional activities of the lawyers themselves in exercising their profession. KCA and disciplinary authorities are mandated to prosecute disciplinary breaches, and depending on cases, impose measures of punishment/sanctioning of the lawyers breaching the Code of Professional Ethics, and influence the functioning of their activities according to the Law on the Bar, Statute and other normative acts. In another view, imposing a disciplinary measure against a lawyer exercising his profession may cause undesired consequences not only for the lawyer, but also for the clients represented by such lawyer.

\section{References}

[1] Constitution of the Republic of Kosovo, Article 111, paragraph 3, p. 44, entering into force on 15 June 2016.

[2] Constitution of the Republic of Albania, Article 42, page 7.

[3] Code of Professional Ethics of the KCA, entering into force on 01 January 2012.

[4] European Convention on Human Rights, Article 6, page 7.

[5] KCA Fees adopted on 20 December 2014, entering into force on 01 January 2015.

[6] Law on the Bar and Legal Aid, Kosovo Assembly, of 19 December 1973.

[7] Law on the Bar, No. 04/L-193, Article 3 para. 1, entering into force on 02 May 2013.

[8] Lawyer's Code of Ethics, adopted by Decision no. 31, of 12. 11. 2005, of the General Council of the National Chamber of Advocates.

[9] Organization for Security and Cooperation in Europe, Guidelines for lawyers in Civil Procedure "Counselling and acts in civil proceedings" 2014, Tirana, p. 13, accessible at

[10] http://www. osce. org/sq/albania/121121?download=true (accessed on 20 March 2016)

[11] Regulation on Regional Branches, adopted on 28 December 2014, entering into force on 01 January 2014.

[12] Regulation on Disciplinary Proceedings, adopted on 16 November 2013, entering into force on 01 January 2014.

[13] Regulation on Compulsory Continued Legal Education for Advocates, adopted on 28 December 2013, entering into force on 01 January 2014.

[14] Regulation on Spatial and Technical Conditions of Law Firms, adopted on 28 December 2013, entering into force on 01 January 2014.

[15] Regulation on Financial Management, adopted on 28 December 2013, entering into force on 01 January 2014.

[16] Regulation on KCA Staff, entering into force on 26 March 2011.

[17] Report by the Office of the Disciplinary Counsel, KCA, 2014, Prishtina, no. 80-4/2014.

[18] Statute of the Kosovo Chamber of Advocates, adopted on 16 November 2013, entering into force on 01 January 2014.

[19] The Council of Bars and Law Societies of Europe (CCBE) CCBE Code of Conduct, Article 1. 1. 